\title{
EFFECT OF AERATION ON HYDROGEN-ION CONCEN- TRATION OF SOILS IN RELATION TO IDENTIFICATION OF CORROSIVE SOILS
}

\author{
By Melvin Romanoff
}

\section{ABSTRACT}

Soils are generally air-dried to obtain comparable results in the measurement of $\mathrm{pH}$. This paper points out the unreliability of such a procedure in measuring the $\mathrm{pH}$ of soils for the identification of corrosive areas. Large changes were observed in hydrogen-ion concentration of a poorly drained soil in passing from the moist field condition to the air-dried state and vice versa. This suggested a further investigation, and 62 air-dried soil samples taken from the National Bureau of Standards soil-corrosion test sites were saturated and stored without air for almost 1 year. Significant changes in $\mathrm{pH}$ were observed in the majority of the samples and large changes in many of them. It has been concluded that, for the identification of areas corrosive to iron and steel, $\mathrm{pH}$ measurements of soils should be made on samples maintained in the natural field condition.

\section{CONTENTS}

I. Introduction

II. Previous studies on $\mathrm{pH}$ values of soils as affected by air-drying _.... 228

III. Effect of aeration on the hydrogen-ion concentration of an anaerobic soil.

1. Description of soil and test location

2. Experimental tests $\ldots \ldots$

3 . Significance of the results with respect to corrosion $\ldots 232$

IV. Effect of saturation and storage with exclusion of air on the $\mathrm{pH}$ values of soils from corrosion test sites

1. Properties of soils

2. Experimental tests

3. Comparison of $\mathrm{pH}$ values of air-dried and deaerated samples_. _ 237

(a) Very poorly and poorly drained soils _............. 237

(b) Well-drained soils $\ldots$

V. Discussion_._. 240

VI. References

\section{INTRODUCTION}

In determining the $\mathrm{pH}$ values of air-dried samples of a soil a few months after the samples had been removed from the field, it was observed that the soil samples were very acid ( $\mathrm{pH} 3.4$ to 4.0 ). These measurements were in sharp contrast to the values obtained in the field, where determinations made on the soil in its natural state 
showed a $\mathrm{pH}$ value of 7.2. Later, samples from the same location were collected and placed in tightly sealed jars and sent to the laboratory, where the $\mathrm{pH}$ determinations were found to be in full agreement with the measurements made in the field. The difference in the $\mathrm{pH}$ values of the soil in the fresh, moist condition and in the air-dried state suggested an investigation of the abnormal behavior of this soil.

\section{PREVIOUS STUDIES ON pH VALUES OF SOILS AS AFFECTED BY AIR-DRYING}

A number of soil investigators have studied the change in $\mathrm{pH}$ value of soil samples in passing from the fresh, moist field condition to the air-dried state. Some have reported that the only reliable measurements of $\mathrm{pH}$ are obtained in the field condition, whereas others have observed no appreciable change between the fresh and the air-dried samples.

Bailey [1] ${ }^{1}$ made an extensive study of the effect of air-drying on 327 moist samples taken at different depths from 64 representative virgin profiles from widely scattered parts of the United States, Puerto Rico, and Canada. The fresh samples were placed in cans which were tightly sealed and sent to the laboratory where the hydrogen-ion measurements were made. The samples were then air-dried and the measurements repeated. Only 42 samples, or 13 percent of the total number examined, changed more than $0.1 \mathrm{pH}$ unit. These 42 samples represented 20 soil profiles, or 31 percent of the profiles studied. Only 2 of the 64 profiles studied contained borizons or layers from which samples changed $0.50 \mathrm{pH}$ unit or more. The maximum change in $\mathrm{pH}$ value was 0.68 . Where the change on drying exceeded $0.1 \mathrm{pH}$, it was in the direction of greater acidity, with only two exceptions. Bailey concluded that hydrogen-ion determinations should be made on air-dried soils rather than on samples fresh from the field. This is in general agreement with Snyder [2], Healy and Karraker [3], Biilmann and Jensen [4], Arrhenius [5], Crowther [6], and Baver [7].

Results obtained by Snyder and by Healy and Karraker showed that air-drying of acid soils lowered the $\mathrm{pH}$ values slightly. Biilmann and Jensen studied 18 soils with a range of $\mathrm{pH} 5.2$ to 8.3 and found that the air-dried soils were slightly more acid than the moist samples. They concluded that the air-dried samples had $\mathrm{pH}$ values which corresponded essentially to the values found before air-drying. Arrhenius reported the effect of drying on the hydrogen-ion concentration of one alkaline soil, finding that air-drying brought about no change. A comparison of fresh soils with air-dried samples by Crowther showed that the $\mathrm{pH}$ was generally reduced (about 0.1 ) by air-drying. The results obtained by Baver indicate that air-drying of acid surface soils does not significantly affect their $\mathrm{pH}$ values. However, air-drying of subsoils causes a marked increase in acidity which becomes greater with depth. He also observed a considerable decrease in alkalinity with alkaline soils. Both Crowther and Baver concluded that, for special purposes and detailed reaction studies, fresh, moist soils should be used in determining the $\mathrm{pH}$, but for ordinary purposes the air-dried samples are sufficiently accurate.

\footnotetext{
1 Figures in brackets indicate the literature references at the end of this paper.
} 
Further information concerning the influence of air-drying soils was also obtained by Burgess [8], McGeorge [9], and Rost and Fieger [10]. Burgess found that drying had little effect on the hydrogen-ion concentration of acid soils. However, the drying of alkaline soils rendered them decidedly less alkaline. McGeorge observed that the $\mathrm{pH}$ values of alkaline calcareous soils were increased slightly by drying the soil in air. The results of Rost and Fieger showed a general tendency for air-dried soils to become more acid than the fresh ones. The acid samples showed as great a change upon air-drying as did the alkaline ones. They concluded that the only reliable indication of conditions existing in the field is obtained when hydrogen-ion determinations are made on soil samples in their natural state.

The effect of moistening and storage upon the hydrogen-ion concentration of samples of soil which had been air-dried was studied by Rost and Fieger [10]. Air-dried samples were remoistened with distilled water and stored in air-tight containers. Hydrogen-ion concentrations were determined at intervals up to 60 days. These investigators concluded that the air-dried samples had hydrogen-ion concentrations no more nearly reliable than the previously dried soils which were remoistened and stored with the exclusion of air.

The season of the year in which the soil sample is taken is of importance in the case of some soils. Periodic fluctuations have been observed in the $\mathrm{pH}$ values of soils by Baver [7], who found that the acid soils studied showed a continuous increase in hydrogen-ion concentration from May to September $(0.92 \mathrm{pH}$ maximum variation) and a return to approximately the same value each spring. He also found that the alkaline soils showed no consistent variation during the same period. Results obtained by Kelley [11] from monthly tests over a period of a year showed variations in $\mathrm{pH}$ values that amounted to as much as $1.0 \mathrm{pH}$ in both surface soil and subsoil. Lipman and coworkers [12] found fluctuations of about $0.7 \mathrm{pH}$ in surface soils between May and November.

From the results of the above-mentioned investigators who studied many different soil types, it is evident why soil samples are generally dried in air in order to obtain comparable results in $\mathrm{pH}$ measurements. In most of the cases the change in the $\mathrm{pH}$ between the fresh sample and the air-dried soil was less than 0.1 unit. A number of the samples changed by as much as several tenths of a $\mathrm{pH}$ unit, and only in a few cases did the variation approach or exceed one $\mathrm{pH}$ unit.

\section{EFFECT OF AERATION ON THE HYDROGEN-ION CONCENTRATION OF AN ANAEROBIC SOIL}

\section{DESCRIPTION OF SOIL AND TEST LOCATION}

The soil samples on which the studies were made were obtained from one of the sites at which corrosion tests are being conducted by the National Bureau of Standards. The site is located in Portage County, Ohio. A section of a pipe line on which severe corrosion caused by the activity of sulfate-reducing bacteria has occurred traverses this test site. The soil was classified as Papakating silty clay loam. The samples were taken at a point where the water table is at the surface of the soil throughout the year; hence, the soil 
is completely saturated at all times, drainage and aeration being very poor.

The Papakating soils belong to a series of soils which have developed in first bottom lands. They have been deposited by the present streams and are the wash from the surrounding uplands, where the bedrock consists primarily of sandstone and shale. As the Papakating series are in the lowest parts of the flood plains of the streams of the region, they are naturally poorly drained and subject to annual overflow. Tile drainage is necessary before the lands can be utilized for anything but pasture.

\section{EXPERIMENTAL TESTS}

The $\mathrm{pH}$ values to be presented were obtained with a $\mathrm{pH}$ electrometer equipped with an inverted liquid junction especially adapted for making $\mathrm{pH}$ determinations of soils. A 1 to 1 soil-water ratio by volume was used for determining the $\mathrm{pH}$ of dried soils. Hereafter where reference is made to the $\mathrm{pH}$ of a dried soil, it will be understood that a 1 to 1 soil-water ratio was used in making the determination. During the measurements the calibration of the instrument was checked at frequent intervals against a standard buffer solution of known $\mathrm{pH}$ value.

A portion of the soil which had been obtained in the fresh, moist state and placed in air-tight containers was exposed to the atmosphere and allowed to dry. Measurements of the $\mathrm{pH}$ values made during the first two weeks showed no appreciable change. However, it is seen in table 1 that on exposure for 6 weeks, the samples became decidedly acid, with a change in $\mathrm{pH}$ value of 3.5 units in one sample, and 3.0 units in the other.

\section{TABLE 1.-Change in $\mathrm{pH}$ value on air-drying soil sample}

\begin{tabular}{|c|c|c|}
\hline Duration of test & Sample 1 & Sample 2 \\
\hline Days & $\begin{array}{l}\mathrm{pH} \\
7.2\end{array}$ & $\begin{array}{l}\mathrm{pH} \\
7.2\end{array}$ \\
\hline $\begin{array}{l}27 \\
38\end{array}$ & 37 & \\
\hline $41 \ldots$ & 0.0 & 4.2 \\
\hline
\end{tabular}

When the soil was dried, its color changed from black to grayish brown. A qualitative test of the fresh soil sample showed the presence of sulfides. A similar test on the aerated sample gave a negative test for sulfides. This showed that the sulfides present in the soil had been oxidized to sulfates on drying.

The changes in $\mathrm{pH}$ shown in table 1 are greater than any reported by previous investigators. However, the change from neutrality to high acidity on aerating soils is not entirely new, since such changes were detected as early as 1886 by Van Bemmelen [13], who showed that soils containing iron sulfide because of the reduction of sulfates by certain bacteria have an acid reaction on being aerated.

Van Bemmelen proved the presence in soils of pyrites and free sulfur formed by reduction of sulfates in the presence of ferric hydroxide. He states that P. J. Kerckhoff was the first to point out that these 
acid soils contain ferrous sulfate, which was probably formed by the oxidation of iron sulfide. After further investigation, Van Bemmelen [13] ascribed the formation of acid in soil to the oxidation of iron sulfide in the form of pyrites. This oxidation results in the formation of ferric sulfate and sulfuric acid when air enters the soil. On hydrolysis, the ferric sulfate changes into yellow basic ferric sulfate and sulfuric acid. If acid soils become anaerobic again, the hydrogen-ion concentration would be expected to diminish gradually until a neutral reaction is attained because of resumption of the sulfate-reduction process.

In order to determine whether the $\mathrm{pH}$ value of the aerated sample could be made to return to the original value observed in the field, airdried samples of the soil were ground and passed through a No. 20 mesh sieve. The soil was saturated with distilled water, which had been previously boiled to remove carbon dioxide, and placed in test tubes. After standing in boiling water for 15 minutes to force the entrapped air out of the saturated soil, the tubes were sealed. Determinations of $\mathrm{pH}$ were made on these stored samples over a period of several months. Table 2 shows the increases observed in the $\mathrm{pH}$ values on storing the samples. A second series in which the soil was treated with $3 \mathrm{ml}$ of sodium lactate solution (containing 60 percent of sodium lactate) per $100 \mathrm{~g}$ of soil is represented by samples 6 and 7 in table 2. It was thought by supplying the sulfate-reducing bacteria with a suitable organic food, their activities might be increased. However, no change was detected by this procedure. Hence, it was assumed that enough organic food was present to favor the growth of the microorganisms.

TABLE 2.-Increase in $\mathrm{pH}$ values of the air-dried samples upon saturation and exclusion of air

\begin{tabular}{|c|c|c|c|c|c|c|c|}
\hline \multirow{2}{*}{ Duration of test } & \multicolumn{5}{|c|}{ Samples moistened with distilled water } & \multicolumn{2}{|c|}{$\begin{array}{l}\text { Samples to which } \\
\text { sodium lactate so- } \\
\text { lution was added }\end{array}$} \\
\hline & 1 & 2 & 3 & 4 & 5 & 6 & 7 \\
\hline Days & $\begin{array}{l}\mathrm{pH} \\
3.9\end{array}$ & $\begin{array}{l}\mathrm{pH} \\
4.0\end{array}$ & $\begin{array}{l}\mathrm{pH} \\
4.0\end{array}$ & $\begin{array}{l}\mathrm{pH} \\
4.0\end{array}$ & $\begin{array}{l}\mathrm{pH} \\
3.8\end{array}$ & $\begin{array}{l}\mathrm{pH} \\
4.0\end{array}$ & $\begin{array}{l}\mathrm{pH} \\
4.0\end{array}$ \\
\hline 15. & 4.9 & - & $-\ldots$ & $-\ldots$ & -..... & & \\
\hline 25 & (n...- & $-1-$ & $-\bar{y}-$ & $-\cdots$ & $--\cdot$ & 4.8 & 4.6 \\
\hline 28. & 5.1 & 5.1 & 5.1 & -.... & $\cdots$ & $-\cdots$ & -...- \\
\hline 38 & $\ldots$ & -.... & (n)..... & (n) & 6.3 & & - \\
\hline 39 & (n....- & 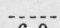 & -..... & $\ldots$ & -..... & 4.8 & 4.8 \\
\hline $\begin{array}{l}42 . \\
49 .\end{array}$ & 6.2 & 6.0 & $+\cdots$ & 4.8 &..-+ & ..... & -..... \\
\hline $54-$ & $-\ldots$ & (n) & ...... & $-\cdots$ & (n) & (n) & 4.8 \\
\hline $\begin{array}{l}57- \\
68\end{array}$ & -...- & 5.8 & 6.8 & 6.2 & $\ldots$ & 6.9 & 65 \\
\hline $\begin{array}{l}68 . \\
69 .\end{array}$ & 7.0 & $\cdots$ & .... & ....... & 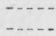 & $\begin{array}{c}0.8 \\
-\ldots . .\end{array}$ & 0.0 \\
\hline 71 & ..... & 6.4 & 7.1 & 6.2 & ...... & 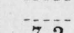 & $=0$ \\
\hline $91 \ldots$ & ..... & $\ldots$ & ....... & 6.9 & ... & 7.2 & 7.0 \\
\hline & & & & & & & \\
\hline
\end{tabular}

It is seen in table 2 that the $\mathrm{pH}$ values of seven samples from the same soil ranged from 3.8 to 4.0 in the air-dried state. After saturation and exclusion of air over a maximum period of 3 months, the soils became approximately neutral. During the change in reaction 
the color of the soil gradually changed from a grayish brown to a dark gray and finally to black.

Table 3 shows the effect of aeration on stored samples which had increased in $\mathrm{pH}$ value to near neutrality. On exposure to the atmosphere for 1 to 2 months, all the samples returned to the extremely acid condition, the $\mathrm{pH}$ values becoming approximately the same as those measured prior to treatment and sealing in the air-tight tubes.

TABLE 3.-Effect of air-drying on the $\mathrm{pH}$ values of previously saturated samples

\begin{tabular}{|c|c|c|c|c|c|c|c|}
\hline \multirow{2}{*}{ Duration of test } & \multicolumn{7}{|c|}{ Sample number } \\
\hline & s 1 & 2 & 3 & 4 & 5 & 6 & 7 \\
\hline Days & $\begin{array}{l}\mathrm{pH} \\
7.0\end{array}$ & pH & $\begin{array}{l}\mathrm{pH} \\
7.1\end{array}$ & $\begin{array}{l}\mathrm{pH} \\
6.9\end{array}$ & $\begin{array}{l}\mathrm{pH} \\
6.3\end{array}$ & $\begin{array}{l}\mathrm{pH} \\
7.2\end{array}$ & $\begin{array}{l}\mathrm{pH} \\
7.0\end{array}$ \\
\hline & (n) & & 6.8 & 6.5 & (n). & 7.1 & 7.0 \\
\hline $\begin{array}{l}20- \\
27\end{array}$ & (n) & $\begin{array}{l}4.4 \\
4.1\end{array}$ & $\begin{array}{l}\text { 4. } 8 \\
\text { 3. } 9\end{array}$ & & - & & \\
\hline $\begin{array}{l}30 . \\
39\end{array}$ & 4.4 & $\ldots$ & $\ldots$ & 5.8 & …- & 4. 2 & 3.9 \\
\hline $\begin{array}{l}49 \\
59\end{array}$ & $-1 .$. & 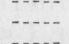 & (n) & 3.8 & 3.4 & (n) & 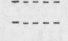 \\
\hline & & & & & & & \\
\hline
\end{tabular}

a The sample number corresponds to the same sample reported in table 2 . The $\mathrm{pH}$ values at 0 days in this table are the maximum values that the samples in table 2 reached.

The data in table 3 show that, on air-drying, reactions take place in the soil which result in a large increase in hydrogen-ion concentration. The data in table 2 indicate that with the exclusion of air from a saturated sample of the previously air-dried soil the reverse reaction takes place. Therefore, it is evident that with respect to $\mathrm{pH}$, this particular soil can be passed through a cycle-from neutrality, as found in the natural field condition, to high acidity, which occurs in the air-dried state, and back to neutrality on resaturation and exclusion of air.

\section{SIGNIFICANCE OF THE RESULTS WITH RESPECT TO CORROSION}

The marked changes in acidity which have been described and the fact that sulfides were detected in the fresh, moist soil and not in the air-dried sample indicate a relation between the observed changes in $\mathrm{pH}$ values and the activity of sulfate-reducing anaerobic bacteria which are known to accelerate corrosion of metals buried in the soil. Under conditions favorable to their growth these bacteria possess the property of reducing sulfates present in the soil to sulfides. The importance of corrosion resulting from the activity of anaerobic bacteria was first reported by von Wolzogen Kühr [14, 15] in Holland. Subsequent investigations carried out by Bunker $[16,17]$ in England, and Hadley $[18,19,20]$ in the United States are in agreement with the findings of von Wolzogen Kühr. Cultures of the bacteria have been prepared from products of corrosion on pipe lines and the bacteria have been studied under the microscope. These investigators have shown that, since the sulfate-reducing spirilla occur in practically every soil, the sulfate-reducing process is encountered throughout the world. The activity of the organisms is claimed to be one of the most 
important causes of corrosion of iron and steel pipe in poorly drained anaerobic soils. Hadley [18] states that the importance of corrosion ascribed to sulfate-reducing bacteria is second only to that caused by stray-current electrolysis.

The conditions favorable to the growth of sulfate-reducing bacteria are (1) presence of moisture, (2) total absence of air (oxygen), (3) presence of assimilable organic compounds and necessary mineral substances (physiological elements), and (4) the presence of sulfate. Hadley [18] observed from investigations in swamps and lowlands that the $\mathrm{pH}$ of the soil water must be approximately 7.0 for the sulfate-reducing spirilla to be active. The limiting deviation noted from this value is $\pm 0.8 \mathrm{pH}$. Hence, other factors being favorable, measurement of $\mathrm{pH}$ is considered an important criterion in the identification of areas corrosive because of sulfate-reducing bacteria.

These bacteria, although becoming dormant in the presence of air, nevertheless require oxygen from some source for their physiological processes. Oxygen is available to the bacteria in the form of some oxygen-containing salt, the most common in soils occurring as sulfate.

In explaining the mechanism of the microbiological sulfate-reduction process with respect to corrosion, the general reaction whereby atomic hydrogen is removed from the cathodic areas may be expressed by the equation:

$$
\mathrm{H}_{2} \mathrm{SO}_{4}+8 \mathrm{H} \longrightarrow \mathrm{H}_{2} \mathrm{~S}+4 \mathrm{H}_{2} \mathrm{O}
$$

By preventing polarization, this reaction permits corrosion to proceed uninterruptedly.

The sulfate-reducing bacteria can be expected to be active in poorly drained anaerobic soils where the soil shows a neutral reaction, if sufficient organic food and sulfates are present for the organisms to thrive on. These are generally soils of heavy texture (clay loams and clays) which would require artificial drainage if used for growing crops. The soils generally occupy flat areas and the water table is near or at the surface. The large changes in $\mathrm{pH}$ value between the fresh and airdried soil samples that have been described occur under these same soil conditions.

\section{EFFECT OF SATURATION AND STORAGE WITH EX- CLUSION OF AIR ON THE PH VALUES OF SOILS FROM CORROSION TEST SITES}

The marked changes in $\mathrm{pH}$ shown by the Papakating soil raises the question whether similar changes might not be of more or less general occurrence in very poorly aerated soils. Since many soils show evidence of deficient aeration in the lower subsoil at the depths at which pipe lines are usually laid, some change in $\mathrm{pH}$ might be expected even in soils in which aeration is considerably better than is true of the Papakating soil. It is, of course, not to be expected that the relationship noted between changes in hydrogen-ion concentration and the oxidation and reduction of sulfur-containing salts would be observed generally, since many factors may produce changes in the $\mathrm{pH}$ values of soils over long periods of standing in contact with water with exclusion 


\section{Journal of Research of the National Bureau of Standards}

of air. For example, increased concentration of ferrous ions resulting from the reducing process would be expected to increase the hydrogen-ion concentration because of hydrolysis of ferrous salts. With certain other classes of soils, namely those containing calcium carbonate or a high content of replaceable bases, production of hydrogen ions within the soil would not be expected to be reflected in appreciable change in hydrogen-ion concentration because of the large buffer action typical of such soils.

So far as the poorly drained soils are concerned, saturation of airdried samples with consequent deoxidation would tend to restore the natural field condition of the soils. Hence, $\mathrm{pH}$ measurements made on soils which have stood in a saturated condition in the laboratory would be expected to represent more nearly the true $\mathrm{pH}$ value of the soils than measurements made directly on the dried samples. With well-aerated soils, on the other hand, saturation would undoubtedly exaggerate the changes in $\mathrm{pH}$ between the two states, and for this reason the method would not be so well adapted to this class of soils. However, in selecting soil samples for further study, it was considered worthwhile to include soils normally classified as well-aerated because of the corrosion which frequently occurs locally in such soils. Because of the wide range in properties shown by the soils in which the soilcorrosion test sites of the National Bureau of Standards are located $[21,22]$, samples of these soils are especially well adapted for the present study.

\section{PROPERTIES OF SOILS}

The properties of the soils shown in table 4 were taken from a previous publication [23]. 
TABLE 4.-Properties of soils in the National Bureau of Standards investigation

A, Alkaline; G, good; F, fair; P, poor; VP, very poor.

[mg-eq =milligram equivalent $]$

\begin{tabular}{|c|c|c|c|c|c|c|c|c|c|c|c|c|c|}
\hline \multicolumn{3}{|c|}{ Soil } & \multirow{2}{*}{$\begin{array}{c}\text { Inter- } \\
\text { nal } \\
\text { drain- } \\
\text { age of } \\
\text { test site }\end{array}$} & \multirow{2}{*}{$\begin{array}{c}\text { Mois- } \\
\text { ture } \\
\text { equiva- } \\
\text { lent }\end{array}$} & \multirow{2}{*}{$\begin{array}{l}\text { Resis- } \\
\text { tivity } \\
\text { at } 60^{\circ} \mathrm{F}\end{array}$} & \multirow{2}{*}{$\begin{array}{c}\text { Total } \\
\text { acidity } \\
\text { mg-eq } \\
\text { per } 100 \\
\text { g of soil }\end{array}$} & \multicolumn{7}{|c|}{ Composition of water extract, mg-eq per $100 \mathrm{~g}$ of soil } \\
\hline No. & Type & Location & & & & & $\begin{array}{c}\mathrm{Na}+\mathrm{K} \\
\text { as Na }\end{array}$ & $\mathrm{Ca}$ & $\mathrm{Mg}$ & $\mathrm{CO}_{3}$ & $\mathrm{HCO}_{3}$ & $\mathrm{Cl}$ & $\mathrm{SO}_{4}$ \\
\hline 1 & Allis silt loam & Cleveland, Ohio. & $P$ & $\begin{array}{c}\% \\
28.6\end{array}$ & $\begin{array}{r}\text { Ohm-cm } \\
1,215\end{array}$ & 11.4 & 0.72 & 0.25 & 0.43 & 0.00 & 0.09 & 0.09 & 0.83 \\
\hline $\begin{array}{l}2 \\
3\end{array}$ & $\begin{array}{l}\text { Bell clay } \\
\text { Cecil clay loam }\end{array}$ & $\begin{array}{l}\text { Dallas, Tex } \\
\text { Atlanta..... }\end{array}$ & $P$ & $\begin{array}{r}37.6 \\
29.1\end{array}$ & $\begin{array}{r}684 \\
30,000\end{array}$ & $\begin{array}{r}3.5 \\
11.5\end{array}$ & .28 & 1.09 & .13 & .00 & 1.18 & .04 & .18 \\
\hline 4 & Chester loam & Jenkintown, $\mathrm{Pa}_{\text {- }}$ & $\stackrel{G}{G}^{G}$ & .22 .12 & $\begin{array}{r}30,000 \\
6,670\end{array}$ & $\begin{array}{r}11.0 \\
7.6\end{array}$ & & & & & & & \\
\hline 5 & Dublin clay adobe. & Oakland, Calif .- & $P$ & 28.8 & 1,346 & 6.5 & .93 & 0.48 & .10 & .00 & 0.69 & .03 & .25 \\
\hline 6 & Everett gravelly sandy loam & Seattle, Wash & $G$ & 12.2 & 45,100 & 12.8 & 100 & & & & & & \\
\hline $\begin{array}{l}7 \\
8\end{array}$ & $\begin{array}{l}\text { Maddox silt loam } \\
\text { Fargo clay loam }\end{array}$ & $\begin{array}{l}\text { Cincinnati, Ohio. } \\
\text { Fargo, N. D }\end{array}$ & $\stackrel{F}{P}$ & $\begin{array}{c}34.3 \\
3.70\end{array}$ & 2,120 & $\stackrel{29.8}{A}$ & & 1.72 & 2,55 & & & & \\
\hline 9 & Genesee silt loam.- & Sidney, Ohio- & $P$ & $\begin{array}{l}3.70 \\
24.8\end{array}$ & $\begin{array}{r}350 \\
2,820\end{array}$ & ${ }_{7.2}^{A}$ & 1.42 & 1.72 & 2.55 & .00 & .71 & .01 & 4.43 \\
\hline 10 & Gloucester sandy loam & Middleboro, Mass & $F$ & 13.0 & 7,460 & 3. 6 & & & & & & & \\
\hline 11 & Hager & Baltimore, Md & $G$ & 32.0 & 11,000 & 10.8 & & & & & & & \\
\hline 12 & sandy los & Los Angeles, Calif. & $G$ & 12.4 & 3,190 & 2.5 & 0.39 & 0.50 & 0.16 & .00 & $.40^{-}$ & $.00^{-}$ & $0.1 \overline{14}$ \\
\hline 13 & Hanford very fine san & $\begin{array}{l}\text { Bakersfield, Calif. } \\
\text { St. Paul, Minn. }\end{array}$ & $\stackrel{F}{F}$ & 21. 7 & $\begin{array}{l}290 \\
520\end{array}$ & $A_{5,6}$ & 6.23 & .09 & .13 & .00 & 1.12 & 1.64 & 3.76 \\
\hline $\begin{array}{l}14 \\
15\end{array}$ & $\begin{array}{l}\text { Hempstead silt loam - } \\
\text { Houston black clay }\end{array}$ & $\begin{array}{l}\text { St. Paul, Minn... } \\
\text { San Antonio, Tex }\end{array}$ & $\stackrel{F}{P}$ & $\begin{array}{l}17.2 \\
51.4\end{array}$ & $\begin{array}{r}3,520 \\
489\end{array}$ & $\begin{array}{l}5.0 \\
5.0\end{array}$ & 2.18 & .88 & .20 & .00 & 2.00 & 0.13 & $0.7 \overline{3}$ \\
\hline 16 & Kalmia fine sandy loam & Mobile, Ala & $F$ & 22.2 & 8,290 & 11.8 & & & & & & & \\
\hline 17 & Keyport 1 & a, Va. & $F$ & 30.8 & 5,980 & 19.1 & & & & & & & \\
\hline 18 & $\mathrm{~K} n \mathrm{O}$ & Nebr-. & $G$ & 28. & 1,410 & 1.4 & 0.27 & .63 & .20 & $.00^{-}$ & 0.94 & .00 & .25 \\
\hline 19 & silt loam. & Des Moines, Iowa & $G$ & 28.4 & 1,970 & 10.9 & .38 & .32 & .41 & .00 & .16 & .03 & .46 \\
\hline 20 & ng silt loam. & Cleveland, Ohio... & $P$ & 22.4 & 2,870 & 1.5 & .25 & .48 & .20 & .00 & .51 & .00 & .15 \\
\hline $\begin{array}{l}21 \\
22\end{array}$ & $\begin{array}{l}\text { silt loam } \\
\text { s silt loam. }\end{array}$ & ity, Mo & $G$ & 31.2 & 2,370 & 9.5 & & & & & & & \\
\hline$b_{23}^{22}$ & $\begin{array}{l}\text { Memphis silt loam. } \\
\text { Merced silt loam.-. }\end{array}$ & $\begin{array}{l}\text { Memphis, Tenn } \\
\text { Buttonwillow, Calif }\end{array}$ & $\stackrel{G}{P}$ & $\begin{array}{l}28.4 \\
24.7\end{array}$ & $\begin{array}{r}5,150 \\
278\end{array}$ & $\stackrel{9.7}{A}$ & 8.38 & .38 & .22 & .02 & 1.87 & 1.12 & 5.57 \\
\hline 24 & Mer & Norv & $G$ & 13.0 & 11,400 & 12.6 & 0.00 & .00 & .22 & .02 & 1.06 & 1.12 & \\
\hline 25 & Miar & Milwaukee, Wis & F & 25.8 & 1,780 & 4.7 & 0.23 & .70 & .41 & $.00^{-}$ & 1.01 & 0.03 & 0.10 \\
\hline 26 & Miami silt loam & Springfield, Ohio & $G$ & 16.4 & 2,980 & 2.6 & .27 & .50 & .31 & .00 & 0.70 & .03 & .12 \\
\hline 28 & Montezuma clay adobe. & Sar & $P$ & 24.6 & 408 & & 1.50 & 0.6 & .18 & .00 & .12 & .99 & .89 \\
\hline 29 & Muck & New Orl & $\overline{V P}$ & 34.5 & 1,270 & 28.1 & 2.15 & 1. 92 & 1. 55 & .00 & .00 & 1. 69 & 2. 30 \\
\hline $\begin{array}{l}30 \\
31\end{array}$ & Muscatine & Davenp & $P$ & 29.4 & 1,300 & 2.6 & 0.32 & 0.65 & 0.40 & .00 & .71 & 0.09 & 0.24 \\
\hline $\begin{array}{l}31 \\
32\end{array}$ & $\begin{array}{l}\text { Norfolk fine sand.- } \\
\text { Ontario loam }\end{array}$ & $\begin{array}{l}\text { Jacksonville, Fla } \\
\text { Rochester, N. Y }\end{array}$ & $\stackrel{G}{G}$ & $\begin{array}{r}2.8 \\
17.8\end{array}$ & $\begin{array}{r}20,500 \\
5,700\end{array}$ & $\begin{array}{l}1.8 \\
0.5\end{array}$ & .23 & & & & 73 & & \\
\hline 33 & Peat...................... & Milwaukee, Wis. & $V P$ & 72.8 & 800 & 36.0 & 1. 52 & 7. 30 & 4. 06 & .00 & .73 & 2. 27 & 2.13 \\
\hline 34 & Pen & & $G$ & 23.4 & 4,900 & 7.0 & & & & & & & \\
\hline 35 & Ran & es, Calif & $F$ & 18.0 & 2,060 & 5.7 & 0.68 & 0.68 & 0.49 & .00 & 1.10 & 0.06 & 0.35 \\
\hline 36 & andy loam. & Meridis & $G$ & 13.8 & 11,200 & 4.6 & & 0.00 & & & 1.10 & 0.00 & \\
\hline 37 & ${ }^{7} \mathrm{St}$. John's fine sand.. & ille, Fla & $P$ & 7. 0 & 11,200 & 15.3 & ..... & & - & -- & - & $\ldots$ & $\cdots$ \\
\hline 38 & Sassafras gravelly sandy loam & $\begin{array}{l}\text { Camden, N. J } \\
\text { Wilmington. Del }\end{array}$ & $\underset{F}{G}$ & $\begin{array}{r}3.0 \\
2.0\end{array}$ & 38,600 & 1.7 & .... & & & & & & \\
\hline $\begin{array}{l}39 \\
40\end{array}$ & 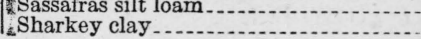 & $\begin{array}{l}\text { Wilmington, Del... } \\
\text { New Orleans. La }\end{array}$ & $\stackrel{F}{P}$ & $\begin{array}{l}24.2 \\
33.0\end{array}$ & $\begin{array}{r}7,440 \\
970\end{array}$ & $\begin{array}{l}0.6 \\
9.4\end{array}$ & 0.56 & 0.58 & 0.44 & 0.00 & 0.93 & - 07 & 0.28 \\
\hline
\end{tabular}


TABLE 4.-Properties of soils a in the National Bureau of Standards investigation-Continued

A, Alkaline; G, good; F, fair; P, poor; VP, very poor.

\begin{tabular}{|c|c|c|}
\hline \multicolumn{3}{|c|}{ Soil } \\
\hline No. & Type & Location \\
\hline 41 & Summit silt loam. & Kansas City, Mo \\
\hline 42 & Susquehanna clay. & Meridian, Miss. \\
\hline 43 & Tidal marsh & Elizabeth, N. J \\
\hline 44 & Wabash silt loam & Omaha, Nebr \\
\hline $\begin{array}{l}45 \\
46\end{array}$ & $\begin{array}{l}\text { Unidentified alkali soll... } \\
\text { Unidentified sandy loam }\end{array}$ & Denver, Colo... \\
\hline 47 & Unidentified silt loam ... & Salt Lake City, Utah \\
\hline 51 & Acadia clay ....... & Spindletop, Tex \\
\hline 53 & Cecil clay loam & Atlanta, Ga...... \\
\hline 55 & Hagerstown loam. & Baltimore, Md. \\
\hline 56 & Lake Charles clay.. & El Vista, Texas.- \\
\hline 58 & Muck & New Orleans, La.. \\
\hline 59 & Carlisle muck & Kalamazoo, Mich. \\
\hline 60 & Rifle peat...... & Plymouth, Ohio ... \\
\hline 61 & Sharkey clay & New Orleans, La. \\
\hline 62 & Susquehanna clay.. & Meridian, Miss - \\
\hline 63 & Tidal marsh & Charleston, S. C. \\
\hline 64 & Docas clay ..... & Cholame, Calif \\
\hline 65 & Chino silt loam & Wilmington, Calif \\
\hline 66 & Mohave fine gravelly loam. & Phoenix, Ariz \\
\hline 67 & Cinders. & Milwaukee, Wis \\
\hline b 70 & Merced silt loam & Buttonwillow, Calif \\
\hline 72 & Papakating silty clay loam & Yale, Ohio ............. \\
\hline
\end{tabular}

[mg-eq=milligram equivalent]

\begin{tabular}{|c|c|c|c|c|c|c|c|c|c|c|}
\hline \multirow{2}{*}{$\begin{array}{l}\text { Inter- } \\
\text { nal } \\
\text { drain- } \\
\text { age of } \\
\text { test site }\end{array}$} & \multirow{2}{*}{$\begin{array}{l}\text { Mois } \\
\text { ture } \\
\text { equiva- } \\
\text { lent }\end{array}$} & \multirow{2}{*}{$\begin{array}{l}\text { Resis- } \\
\text { tivity } \\
\text { at } 60^{\circ} \mathrm{F}\end{array}$} & \multirow{2}{*}{$\begin{array}{c}\text { Total } \\
\text { acidity } \\
\text { mg-eq } \\
\text { per } 100 \\
\text { g of soil }\end{array}$} & \multicolumn{7}{|c|}{ Composition of water extract, mg-eq per $100 \mathrm{~g}$ of soil } \\
\hline & & & & $\begin{array}{c}\mathrm{Na}+\mathrm{K} \\
\text { as Na }\end{array}$ & $\mathrm{Ca}$ & $\mathrm{Mg}$ & $\mathrm{CO}_{3}$ & $\mathrm{HCO}_{3}$ & $\mathrm{Cl}$ & $\mathrm{SO}_{4}$ \\
\hline$F$ & $\begin{array}{l}\% \\
33.1\end{array}$ & $\begin{array}{r}\text { Ohm-cm } \\
1,320\end{array}$ & 11.0 & 0.30 & 0.54 & 0.36 & 0.00 & 0.78 & 0.04 & 0.46 \\
\hline$P$ & 34.8 & 13,700 & 28.2 & & & & & & & 3700 \\
\hline$\underset{G}{V P}$ & $\begin{array}{l}55.4 \\
31.2\end{array}$ & $\begin{array}{r}60 \\
1,000\end{array}$ & $\begin{array}{r}36.8 \\
8.8\end{array}$ & $\begin{array}{r}45.10 \\
1.05\end{array}$ & $\begin{array}{l}5.17 \\
1.08\end{array}$ & & .00 & $\begin{array}{r}.00 \\
1.97\end{array}$ & $\begin{array}{r}43.30 \\
0.82\end{array}$ & $\begin{array}{r}37.00 \\
0.41\end{array}$ \\
\hline$P$ & 14. & 263 & $A$ & 8. & & & .00 & 4 & & 11. 98 \\
\hline$\stackrel{G}{P}$ & $\begin{array}{r}.6 \\
25.7\end{array}$ & $\begin{array}{l}1,770 \\
1,770\end{array}$ & 3.0 & $0.67^{-}$ & 0. & 39 & .00 & .88 & .06 & 0.48 \\
\hline$V P$ & & 190 & 13. 2 & 10.27 & 15.55 & 5.03 & .00 & .56 & 5. 75 & 22.00 \\
\hline$G$ & & 17,794 & & & & & & & & \\
\hline 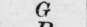 & & 5, & & & & & & & & \\
\hline$P$ & & 6 & 5 & 3.12 & 0. & 0.4 & .00 & .80 & 1. 59 & 3. 04 \\
\hline$V P$ & & 712 & & & & & & & & 2. \\
\hline & & 1,659 & & & & & & .0 & & 1. \\
\hline$\stackrel{V}{V P}$ & & 218 & 297.4 & 2.9 & 10. & & .0 & .0 & .00 & 56.70 \\
\hline$P$ & 30 & 943 & 8.6 & 0.73 & 0.68 & 0.33 & .00 & .71 & .10 & 0.91 \\
\hline$\stackrel{P}{V P}$ & 34 & 6,922 & $\begin{aligned} 24 . & 2 \\
100 . & 0\end{aligned}$ & 3 & & 400 & 00 & 00 & 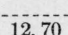 & 36.60 \\
\hline $\begin{array}{l}V P \\
V P\end{array}$ & & 8 & 100.2 & & & & & & & 36. \\
\hline & & 148 & $A$ & & $\begin{array}{r}12.40 \\
\text { 12. }\end{array}$ & & .0 & & & 16. \\
\hline$G$ & 16. & 232 & $A$ & 6.5 & 0.51 & 0.1 & .0 & 0.73 & 2. & 2. 97 \\
\hline$V P$ & 11 & 455 & $A$ & & & & .0 & .5 & & \\
\hline$\stackrel{P}{V P}$ & 24.7 & 278 & $A$ & 8. 38 & 0.38 & .22 & .02 & 1. 87 & 1. 12 & 5.57 \\
\hline
\end{tabular}

a Measurements and determinations by I. A. Denison and R. B. Hobbs.

b The soils are from the same test site. 


\section{EXPERIMENTAL TESTS}

Two samples of each of 62 air-dried soils were saturated with previously boiled distilled water and placed in test tubes or small bottles. After allowing the tubes to stand in boiling water for 15 minutes to force the entrapped air out of the saturated soil, 10 to 15 $\mathrm{ml}$ of distilled water was added and the tubes sealed and stored. Measurements of $\mathrm{pH}$ and a qualitative test for the presence of sulfides were made on the air-dried samples before the treatment was applied. No sulfides were found in any of the air dried samples. Measurements of $\mathrm{pH}$ were made on the stored samples after approximately 120 and 350 days. At the end of the 350-day period the samples were also tested for the presence of sulfides.

\section{COMPARISON OF $\mathrm{pH}$ VALUES OF AIR-DRIED AND DEAERATED SAMPLES}

\section{(a) VERY POORLY AND POORLY DRAINED SOILS}

The effect of deaeration on the $\mathrm{pH}$ values of the very poorly and poorly drained soils is shown in tables 5 and 6 . The muck soils (29 and 58), the peat (33), and the very heavy Acadia clay (51) show the trend noted in the case of the Papakating soil with respect both to marked increase in hydrogen-ion concentration and reduction of sulfates to sulfides. Since these soils contain an abundance of organic matter and sulfates and have $\mathrm{pH}$ values close to neutrality, the environmental conditions are well adapted for supporting the activity of anaerobic bacteria. The tidal marsh soils $(43,63 \mathrm{~A}$, and $63 \mathrm{~B})$ and the peat soils $(60 \mathrm{~A}$ and $60 \mathrm{~B})$ contain in abundance the essential elements required for sulfate-reduction, namely organic matter and sulfates, but their $\mathrm{pH}$ values ranging from 2.87 to 3.45 are too low to permit bacterial activity. This is indicated by the lack of change in $\mathrm{pH}$.

TABLE 5.-Change in $\mathrm{pH}$ values of air-dried samples upon saturation and exclusion of air

[Drainage of soils, very poor]

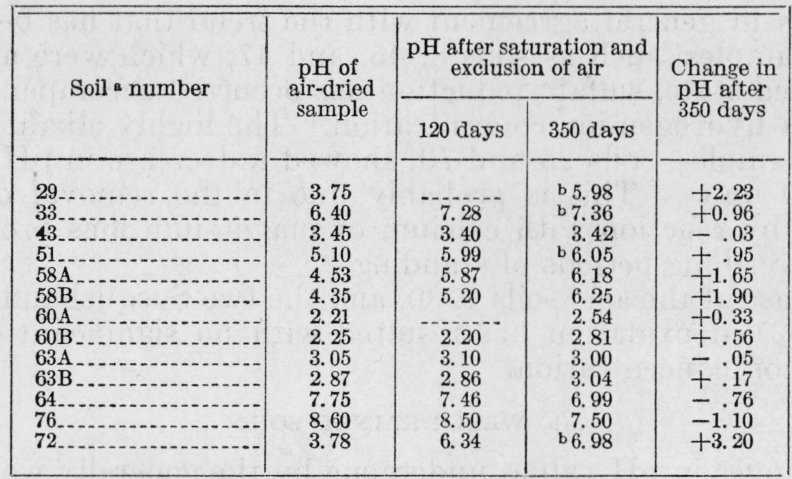

See table 4 for soil type, locations, and properties of the soils.

b These samples gave a positive test for sulfides. 
TABLE 6.-Change in $\mathrm{pH}$ values of air-dried samples upon saturation and exclusion of air

[Drainage of soils, poor]

\begin{tabular}{|c|c|c|c|c|}
\hline \multirow{2}{*}{ Soil number } & \multirow{2}{*}{$\begin{array}{l}\mathrm{pH} \text { of air- } \\
\text { dried } \\
\text { sample }\end{array}$} & \multicolumn{2}{|c|}{$\begin{array}{l}\mathrm{pH} \text { after saturation } \\
\text { and exclusion of air }\end{array}$} & \multirow{2}{*}{$\begin{array}{c}\text { Change in } \\
\text { pH after } \\
350 \text { days }\end{array}$} \\
\hline & & 120 days & 350 days & \\
\hline $\begin{array}{l}1 \\
50 \\
8 \\
9 \\
8 \\
8\end{array}$ & $\begin{array}{l}4.56 \\
6.70 \\
5.75 \\
7.81 \\
6.90 \\
7.30 \\
5.75 \\
8.88 \\
3.99 \\
6.62 \\
3.72 \\
6.27 \\
4.36 \\
8.22 \\
7.92 \\
7.22 \\
5.66 \\
6.22 \\
4.07 \\
8.71\end{array}$ & $\begin{array}{l}4.58 \\
7.14 \\
7.14 \\
7.29 \\
6.96 \\
7.19 \\
5.98 \\
7.65 \\
4.31 \\
6.62 \\
4.22 \\
7.35 \\
4.82 \\
7.47 \\
7.58 \\
7.23 \\
6.30 \\
7.03 \\
4.12 \\
7.58\end{array}$ & $\begin{array}{r}4.55 \\
\text { a } 7.10 \\
\text { a } 7.02 \\
\text { a } 6.98 \\
\text { a } 7.35 \\
\text { a.35 } \\
5.94 \\
6.90 \\
4.90 \\
6.58 \\
4.19 \\
7.31 \\
4.35 \\
\text { a } 6.80 \\
\text { a } 7.05 \\
\text { a } 7.24 \\
6.45 \\
7.03 \\
4.10 \\
6.72\end{array}$ & $\begin{array}{r}-0.01 \\
+.40 \\
+1.27 \\
-0.83 \\
+.45 \\
+.05 \\
+.19 \\
-1.98 \\
+0.91 \\
-.04 \\
+.47 \\
+1.04 \\
-0.01 \\
-1.42 \\
-0.87 \\
+.02 \\
+.79 \\
+.81 \\
+.03 \\
-1.99\end{array}$ \\
\hline
\end{tabular}

a These samples gave a positive test for sulfides.

The Houston black clay (15) and Lake Charles clay (56) have undergone sulfate-reduction without any appreciable change in hydrogen-ion concentration. These soils contain either calcareous material or very high contents of absorbed bases and no change in $\mathrm{pH}$ from reduction of sulfates would be anticipated. In order for an increase in hydrogen-ion concentration to take place on air-drying, there must be a low buffer capacity in the soil. Hissink [24] states that the formation of acid due to the oxidation of accumulated sulfides can produce higher degrees of acidity only if there are no basic elements present in the soil. Hence, if a soil is plentifully supplied with bases, e. g., soils of high lime content, the oxidation of the sulfides to sulfates may cause no significant change in reaction.

The behavior of the poorly drained soils from sites 2,5 , and 9 (table 6) is in general agreement with the trend that has been noted. In some samples, such as soils 8,45 , and 47 , which were alkaline in the air-dried state, sulfate-reduction has occurred accompanied by an increase in hydrogen-ion concentration. The highly alkaline Merced silt loam samples, soils 23 and 70 , showed a decrease in $\mathrm{pH}$ value by almost 2.0 units. This is probably due to the removal of sodium carbonate by reaction with calcium or magnesium ions brought into solution over long periods of standing.

In the case of the acid soils 1, 30, and the two Susquehanna samples (42 and 62), deoxidation has resulted with no significant change in hydrogen-ion concentration.

\section{(b) WELL-DRAINED SOILS}

The changes in $\mathrm{pH}$ values undergone by the generally well-drained soils are shown in tables 7 and 8 . As has been stated, the purpose of the treatment to which the air-dried samples were subjected, namely, saturation and storage with exclusion of air, was to restore the natural 
condition of the soil. Obviously this condition has not been realized for the class of well-aerated soils under consideration, because a deoxidized condition has been substituted for the normal oxidized state. For this reason, for the soils listed in tables 7 and 8 the method is too drastic. However, it has been observed [25] that severe corrosion often occurs locally in soils of normally good drainage where corrosion ordinarily would not be predicted. Corrosion in such soils does not occur generally throughout the soil type, but is confined to restricted areas of deficient aeration that are too small in their extents to be properly classified. Mottling close to the surface may usually be found in such areas. These local areas in which reduction by bacterial processes would be expected to occur might be entirely overlooked if $\mathrm{pH}$ measurements were confined to air-dried samples.

TABLE 7.-Change in $\mathrm{pH}$ values of air-dried samples upon saturation and exclusion of air

[Drainage of soils, fair]

\begin{tabular}{|c|c|c|c|c|}
\hline \multirow{2}{*}{ Soil number } & \multirow{2}{*}{$\begin{array}{l}\mathrm{pH} \text { of } \\
\text { air-dried } \\
\text { sample }\end{array}$} & \multicolumn{2}{|c|}{$\begin{array}{l}\mathrm{pH} \text { after saturation and } \\
\text { exclusion of air }\end{array}$} & \multirow{2}{*}{$\begin{array}{l}\text { Change in } \\
\text { pH after } \\
350 \text { days }\end{array}$} \\
\hline & & 120 days & 350 days & \\
\hline 16 & $\begin{array}{r}4.55 \\
4.63 \\
10.56 \\
7.31 \\
4.75 \\
4.20 \\
7.73 \\
7.53 \\
4.94 \\
7.24 \\
8.06\end{array}$ & $\begin{array}{l}4.30 \\
5.25 \\
9.25 \\
6.93 \\
6.39 \\
5.30 \\
7.33 \\
7.70 \\
5.50 \\
7.45 \\
7.28\end{array}$ & $\begin{array}{r}5.35 \\
\text { ๙ } 7.90 \\
5.95 \\
6.92 \\
5.45 \\
7.23 \\
7.20 \\
5.45 \\
\text { 7. } 20 \\
7.19\end{array}$ & $\begin{array}{r}+0.72 \\
-2.66 \\
-1.36 \\
+2.17 \\
+1.25 \\
-0.50 \\
-.33 \\
+.56 \\
-.04 \\
-.87\end{array}$ \\
\hline
\end{tabular}

- These samples gave a positive test for sulfides.

TABLE 8.-Change in $\mathrm{pH}$ values of air-dried samples upon saturation and exclusion of air

[Drainage of soils, good]

\begin{tabular}{|c|c|c|c|c|}
\hline \multirow{2}{*}{ Soil number } & \multirow{2}{*}{$\begin{array}{l}\mathrm{pH} \text { of } \\
\text { air-dried } \\
\text { sample }\end{array}$} & \multicolumn{2}{|c|}{$\begin{array}{l}\mathrm{pH} \text { after saturation } \\
\text { and exclusion of air }\end{array}$} & \multirow{2}{*}{$\begin{array}{l}\text { Change in } \\
\text { pH after } \\
350 \text { days }\end{array}$} \\
\hline & & 120 days & 350 days & \\
\hline 11A $\mathrm{A}$ & $\begin{array}{l}4.82 \\
4.60 \\
4.85 \\
5.71 \\
6.22 \\
6.73 \\
7.03 \\
4.91 \\
5.95 \\
4.88 \\
5.18 \\
7.60 \\
5.60 \\
7.62 \\
5.86 \\
5.20 \\
4.50 \\
6.13 \\
7.00 \\
4.80 \\
5.94 \\
8.84\end{array}$ & $\begin{array}{l}5.76 \\
5.54 \\
5.86 \\
-6.75 \\
7.52 \\
7.60 \\
5.89 \\
6.56 \\
5.06 \\
5.88 \\
7.51 \\
6.12 \\
7.40 \\
6.50 \\
6.52 \\
4.82 \\
6.91 \\
6.94 \\
5.39 \\
6.18 \\
8.05\end{array}$ & $\begin{array}{r}5.94 \\
5.57 \\
6.42 \\
5.80 \\
7.15 \\
7.70 \\
7.70 \\
5.76 \\
\text { a } 6.65 \\
5.30 \\
5.50 \\
6.55 \\
6.15 \\
7.45 \\
5.91 \\
\text { a } 6.49 \\
6.10 \\
6.35 \\
6.93 \\
5.13 \\
6.53 \\
8.20\end{array}$ & $\begin{array}{l}+1.12 \\
+0.97 \\
+1.57 \\
+0.09 \\
+.93 \\
+.97 \\
+.67 \\
+.85 \\
+.70 \\
+.42 \\
+.32 \\
-1.05 \\
+0.55 \\
+.17 \\
+.05 \\
+1.29 \\
+1.60 \\
+0.22 \\
+.07 \\
+.33 \\
+.59 \\
-.64\end{array}$ \\
\hline
\end{tabular}

- These samples gave a positive test for sulfides. 


\section{DISCUSSION}

The $\mathrm{pH}$ values measured after storage in the saturated condition represent extreme values which might be expected in nature if the soils should become completely deaerated over a long period. Since few of the soils at the corrosion test sites are known to be in this condition except temporarily, the values presented for the saturated soils cannot be considered as replacing values of $\mathrm{pH}$ previously reported, although there is no doubt that the values in the moist condition represent more nearly the $\mathrm{pH}$ of at least the very poorly aerated soils in their field condition. However, the data clearly indicate that the true $\mathrm{pH}$ of many of the soils can be measured accurately only with the soil in the field condition. If the measurements are to be made in the laboratory, the samples must obviously be preserved in the natural field condition. It is planned at a convenient time to measure the $\mathrm{pH}$ values of soils at the corrosion test sites according to the revised procedure.

As it has been shown that the $\mathrm{pH}$ of soils is subject to variation depending on variations in climate and other factors $[7,11,12]$, the recommended procedure of measuring the $\mathrm{pH}$ of soils under field conditions raises the question of reproducibility. Some degree of reproducibility will almost certainly be sacrificed, but this loss will be more than offset by the gain in accuracy obtained at least in the case of the poorly drained soils.

In view of the data presented, it can be concluded that for the identification of areas corrosive to iron and steel it is preferable to measure the $\mathrm{pH}$ of soils in their natural condition or on samples maintained in the field condition. Unless the $\mathrm{pH}$ of soils is properly measured, the conclusion is likely to be drawn that corrosion resulting from bacterial activity in some soils is unimportant, whereas, it may, in fact, be particularly severe.

\section{REFERENCES}

[1] E. H. Bailey, The Effect of Air Drying on the Hydrogen-ion Concentration of the Soils of the United States and Canada, U. S. Dept. Agr. Tech. Bul. 291 (1932).

[2] E. F. Snyder, Methods for Determining the Hydrogen-ion Concentration of Soils, U. S. Dept. Agr. Cir. 56 (1935).

[3] D. J. Healy and P. E. Karraker, The Clark hydrogen-electrode vessel and soil measurements, Soil Sci. 13, 323 (1922).

[4] E. Biilmann and S. Tovborg Jensen, On the Determination of the Reaction of Soils by Means of the Quin-hydron Electrode, International Society Soil Science Transactions Communication 2 (B), p. 261 (1927).

[5] O. Arrhenius, The potential acidity of soils, Soil Sci. 14, 223 (1922).

[6] E. M. Crowther, Studies of soil reaction. III. The determination of the hydrogen-ion concentration of soil suspensions by means of the hydrogen electrode, J. Agr. Sci. (England) 15, 201 (1925).

[7] L. D. Baver, Factors affecting the hydrogen-ion concentration of soils, Soil Sci. 23, 399, (1927).

[8] P. S. Burgess, The hydrogen-ion concentration as affected by drying, Science [N. S.] 55, 647, (1922).

[9] W. T. McGeorge, The Measurement and Significance of Hydrogen-ion Concentration in Alkaline-Calcareous Soils, Ariz. Agr. Expt. Sta. Tech. Bul. 57 (1935).

[10] C. O. Rost and E. A. Fieger, Effect of drying and storage upon the hydrogen-ion concentration of soil samples, Soil Sci. 16, 121 (1923).

[11] A. P. Kelley, Soil acidity, an ecological factor, Soil Sci. 16, 41 (1923). 
[12] J. G. Lipman, A. L. Prince, and A. W. Blair, The influence of varying amounts of sulfur on the soil, on crop yields, hydrogen-ion concentration, lime requirement, and nitrate formation, Soil Sci. 12, 197 (1921).

[13] J. M. Van Bemmelen, Contribution to the Knowledge of Alluvial Soil in the Netherlands, Treatise of the Royal Academy of Science, 25th part, p. 34, 67 , and 95 (1886).

[14] C. A. H. von Wolzogen Kühr and L. S. Van der Vlugt, The graphitization of cast iron as an electro-biochemical process in ancerobic soils, Water (Holland), 18, 147 (August 1934).

[15] C. A. H. Von Wolzogen Kühr, Sulphate reduction as the cause of corrosion of iron pipe lines, Water and Gas (Holland), $\boldsymbol{\gamma}$ (No. 26) 277 (1923).

[16] H. J. Bunker, The role of the sulphate-reducing bacteria in metallic corrosion, Proc. Brit. Assoc. of Refrig. 33 (No. 1) 151 (1936-37).

[17] H. J. Bunker, Micro-biological experiments in anaerobic corrosion, J. Soc. Chem. Ind. (London) 58, 93, (March 1939).

[18] R. F. Hadley, Microbiological anaerobic corrosion of steel pipe lines, Oil Gas J. 38 (No. 19) 92 (1939).

[19] R. F. Hadley, Methods of studying microbiological anaerobic corrosion of pipe pipe lines, Petroleum Engr., Part 1, 11, (No.6) 171; part 2, 11 (No. 7) $112(1940)$.

[20] R. F. Hadley, Studies on Microbiological Anaerobic Corrosion, Proc. Am. Gas Assn., p. 764 (1940).

[21] K. H. Logan, S. P. Ewing, and C. D. Yeomans, Bureau of Standards SoilCorrosion Studies. I. Soils, Materials, and Results of Early Observations, Tech. Pap. BS 22, 447 (1927-28) T368.

[22] K. H. Logan and M. Romanoff, Soil-corrosion studies, 1941. Ferrous and nonferrous corrosion resistant materials and nonbituminous coatings, J. Research NBS 33, 145 (1944) RP1602.

[23] K. H. Logan, Soil-corrosion studies, 1934. Rates of loss of weight and penetration of nonferrous materials, J. Research NBS 17, 781 (1936) RP945.

[24] D. J. Hissink, Chem. Weekblad (Chemical Weekly), No. 39, p. 632 (1933).

[25] I. A. Denison and R. B. Darnielle, Correlation of an electrolytic corrosion test with the actual corrosiveness of soils, J. Research NBS 21, 819 (1938) RP1157.

Washington, November 24, 1944. 